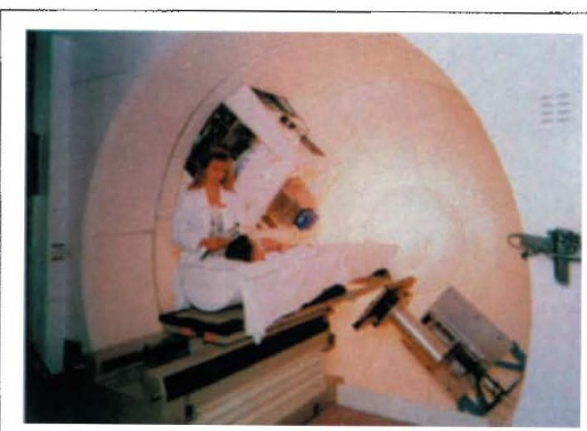

The U.S.'s only proton treatment facility at Loma Linda University Medical Center.

near Geneva, and Giampiero Tosi at the European Institute of Oncology in Milan. Most of the cost of the project is to be met by public funds from the regional government and the ministries of health and research.

The two existing centers are the $\$ 80$ million Loma Linda U.M.C. Proton Treatment Center in the US, which opened in 1992, and the $\$ 350$-million Heavy Ion Medical Accelerator Center in Japan, which has been operating since 1994. The Italian center, the only European project at such an advanced stage, "will place Italy in the forefront" for this form of cancer therapy, says Amaldi.

Hadron therapy provides more selective irradiation of tumors than conventional radiotherapy. Researchers say it may be useful where tumors are deep-seated or close to critical structures in the body, or where tumors are resistant to X-rays. So far, however, its advantages over conventional radiotherapy have been demonstrated only for melanomas and tumors of the spinal cord. Although more patients are expected to benefit from hadron therapy in the future, researchers are still awaiting data from large, randomized clinical trials.

Critics of the project fear that it will drain money from more urgently needed health care. But Umberto Veronesi, Director of the European Institute of Oncology in Milan, rejects the critics' fears. In future, he says, doctors will be able to diagnose many common tumors at an earlier stage than is currently possible. Since very small lesions are likely to be well suited to hadron therapy, the decision to develop this approach now is likely to pay off, he says. "To serve our patients better in the future, it is a must to invest now in highly promising treatments."

MaRTINA BALLMAIER Milan

\title{
U.K. scientists guarded as Battle takes up science brief
}

Biomedical researchers in Britain are waiting cautiously to find out how the Labour government's appointment of a Catholic as science minister will affect them. John Battle spent three years training for the Roman Catholic priesthood before entering university, and worked for a group called Church Action for Poverty before entering Parliament in 1987. As the Labour party's spokesman on science and technology between 1994 and 1995, Battle, earned high marks among researchers for his enthusiasm and commitment. He was equally successful as his party's energy spokesman, a post that led directly to his appointment as a minister in the Department of Trade and Industry after Labour's decisive election victory in May.

Battle will have a wide brief covering industry, energy and science. His initial public statements have closely re-

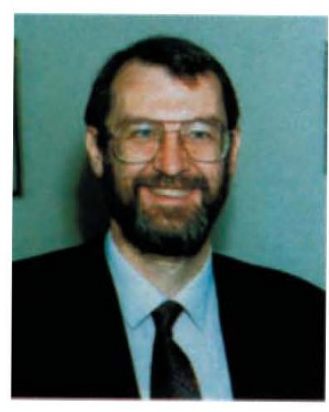

Britain's new science minister, John Battle. flected the Labour party's pre-election commitment to place science "at the heart of government", as well as the need to put innovation at the center of economic policy. Battle has already said, for example, that one of his top priorities is to provide a new impetus to the Technology Foresight program, launched by the previous Conservative government in 1993 with the aim of improving the interaction between academics and industry.

On issues like these, Battle is expected to stay close to the Labour party's official thinking including a reluctance to impose yet another shake-up on Britain's research community. But on a separate agenda - the social and ethical issues raised by biomedical science - Battle's position is less predictable.

In areas such as human genetics and embryology, Battle's personal views could prove to be important. His religious beliefs were reflected on two separate occasions in opposition when he voted against those whom he believed were seeking an excessive liberalization of the abortion laws. As a result, he has attracted accusations in the press of having an "evangelical streak", and raised fears that he could oppose embryological research, for example, on religious grounds.

Battle has made no formal response to such comments. His supporters point out that his commitment to religious tolerance - as well as to grass-roots politics and a concern for social welfare - makes it highly unlikely that he will adopt an extreme position against embryo research. Nevertheless, his personal views could still have an impact. Battle is responsible for the Office of Science and Technology, which, among its many other activities, administers the Human Genetics Advisory Board, set up by the previous government to monitor the regulation of genetics research and its applications. And Battle could, at least in principle, influence the outcome of key debates, such as whether Britain ratifies decisions taken by the Council of Europe's bioethics convention. The convention forbids research using human embryos, a practice currently permitted in Britain, although under strictly regulated conditions.

The terms of the European convention allow individual countries to exclude themselves from certain clauses. If, as seems likely, this issue comes up for debate in Parliament, some observers believe that Britain will face stronger public demands to curb embryo research in line with the convention than it did in 1990 , when the legislation allowing certain types of such research was passed.

DAVID Dickson London

\section{Correction}

On page 595 of the June issue, a photograph of Sir David Barnes was incorrectly labelled as Bernard Salick. We regret the error.

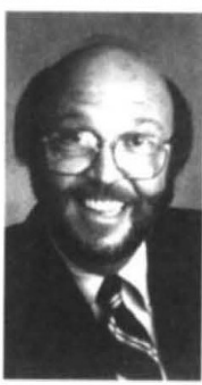

Bernard Salick 